\title{
Effects of Different Additives on the Growth Performance and Carcass Characteristics of Holstein Steers
}

\author{
Won Mo Cho ${ }^{1}$, Sung Hak Yang ${ }^{1}$, Sang Min Lee ${ }^{1}$, Sun Sik Jang ${ }^{1}$, Hyeong Cheol Kim', \\ Seong Koo Hong', Woon Yeoul Park ${ }^{2}$ and Hyun Soo Kim ${ }^{3}$ \\ ${ }^{1}$ National Institute of Animal Science, RDA, Pyeongchang 232-950, Korea \\ ${ }^{2}$ Samyang corporation, Seoul 110-725, Korea \\ ${ }^{3}$ Sine-Bio corporation, Sungnam 462-721, Korea
}

Received September 28, 2011 /Revised January 13, 2012 /Accepted January 13, 2012

\begin{abstract}
This study was performed to investigate the feeding effects of different additives on the growth performance and carcass characteristics of Holstein steers. Twenty-four Holstein steers, five months of age and $176.6 \mathrm{~kg}$, were randomly allocated to three experimental groups of eight animals each for an 18-month feeding trial. The groups were control (not additive), T1 (fed zinc, vitamin C, and sulfur), and T2 (fed choline and lysine). The average daily gain was no different between the treatment groups during the growing to early fattening period, but it was significantly higher in the T1 group than the T2 group in the late fattening period $(p<0.05)$. The final BW of the T1 group was relatively high in relation to the other groups, but was not significantly different. The additives had no effects on DMI during the experimental period; however, the feed conversion ratio of the T1 group in the late fattening period was significantly lower than that of the T2 group $(p<0.05)$. The results of yield traits, carcass weight, and yield index were similar between groups, but back fat thickness and rib eye area were relatively lower in the T2 group than in the other groups. In terms of quality traits, meat color, texture, and maturity were not significantly different between the three groups. However, marbling score and appearance rate of high quality grade $\left(1^{++}, 1^{+}\right.$, and 1$)$ were higher in the T1 group compared with the T2 group. Thus, the present results suggest that vitamin $C$, zinc, and sulfur supplementation may improve the growth performance and carcass characteristics of Holstein steers.
\end{abstract}

Key words : Growth performance, carcass characteristics, Holstein steers, additives

\section{서 론}

우리나라에서 연간 출하되는 육우는 전체 도축물량의 $12 \%$ 를 차지하며, 이 중 대부분이 홀스타인 수소 및 거세우이다. 하지만, 육우인 홀스타인의 경우 육질등급 출현율이 낮아 한 우 거세우(평균 30개월 출하)에 비해 짧은 기간 비육되어 출하 되고 있는 실정이다. 한우에 비하여 육우는 육질등급이 낮아 시장 가치가 낮고 고품질을 선호하는 소비자에게도 소외되어 왔다. 최근 농가 소득향상과 저가의 수입 쇠고기에 대한 대책 으로 국내산 육우의 품질 및 생산성 향상에 관한 관심이 증가 되고 있고, 국내산 육우의 생산성 및 육질 향상을 위해 전략적 인 영양소 공급이 이루어져야 할 것이다.

영양학자들은 동물의 생산성 향상을 위해 영양소의 기능 및 적정 요구량을 밝히고자 노력해 왔는데 이러한 물질들 중 아연은 필수영양소로 효소작용과 단백질의 유전자 발현과 동 물의 번식, 성장, 유생산 및 면역체계에 영향을 주고[4,19], 유 황은 반추동물에 필수 유기영양소 중 하나로 반추위 내 셀룰 로스와 전분 분해에 효과가 있다고 보고하였다[2,6,10]. 또한

*Corresponding author

Tel : +82-33-330-0659, Fax : +82-33-330-0660

E-mail : cwmo3451@korea.kr
비타민 C는 수용성 항산화제로서 섬유와 골격세포 및 collagen 형성에 중요한 영양소[16]이며 우육의 육색을 개선하고 지방산화를 억제한다고 알려져 있고[8], 비타민 B 복합체에 속 하는 수용성의 필수 영양소인 콜린(choline)은 발육 및 사료요 구율을 향상시키는 것으로 알려져 있으며[5], 라이신(Lysine) 은 비육우에 있어 제한아미노산으로 분류되며[9] 비육우의 증 체 혹은 사료효율을 개선하고[21], 반추위 보호지방과 함께 급 여 시 근내지방을 향상시키는 것으로 알려져 있다[14].

이러한 다양한 영양소의 급여는 반추동물의 생산성 및 육질 향상에 도움을 줄 것으로 판단되며, 따라서 본 연구는 발육 및 육질 향상을 위해 여러 가지 기능성 물질을 혼합하여 홀스 타인 거세우에 급여함으로써 발육 및 도체특성에 미치는 영향 을 구명하고자 수행하였다.

\section{재료 및 방법}

\section{공시동물 및 사양관리}

본 연구는 생후 5 개월령(평균체중 $176.6 \mathrm{~kg}$ ) 홀스타인 수소 24 두를 공시하여 거세 후 시험축으로 이용하였고, 사양관리는 육성기(5 10개월령), 비육전기(11 16개월령) 및 비육후기 (17 22개월령)로 성장단계를 구분하여 성장단계별로 배합사 
료 급여량은 각각 체중의 $1.8 \sim 2.2 \%$ 및 자유채식을 원칙으로 하루 두 번(08:00 및 16:00) 균등분배 하였고, 조사료는 육성기 에는 호밀, 티모시에 볏짚을 혼합, 비육기에는 볏짚만 급여하 였다. 조사료 급여는 전기간 동안 자유채식토록 하였다. 첨가 제는 오전사료 급여 시 처리구별로 두당 $100 \mathrm{~g}$ 씩 Top dressing 하여 급여하였다. 미네랄 블록 및 물은 항상 자유롭게 섭취할 수 있도록 하였다.

\section{시험사료}

공시동물에 급여한 배합사료는 시판되는 육우용 사료 (Table 2)를 이용하였고, 조사료는 호밀과 티모시, 볏짚을 이 용하였고, 첨가제는 Table 1의 성분비에 맞추어 주문 생산하 여 시험에 이용하였다. 시험에 이용된 사료의 일반성분은 Table 3에 나타내었다.

\section{시험설계}

본 연구의 처리구 배치는 대조구(무처리)와 육질개선을 위한 첨가물질 급여구인 $\mathrm{T} 1$ (아연, 비타민 $\mathrm{C}$, 유황 첨가구) 및 $\mathrm{T} 2$ (콜린 및 lysine 첨가구)로 나누어 8 반복으로 완전 임

Table 1. Ingredients of feed additives used this experiment (DM basis)

\begin{tabular}{lcc}
\hline Item & T1 & T2 \\
\hline Zinc & 0.03 & - \\
Vitamin C & 5.05 & - \\
sulfur & 1.00 & - \\
Choline & - & 32.00 \\
Lysine & - & 16.30 \\
Protected fatty acid & 93.92 & 51.70 \\
\hline
\end{tabular}

의배치 하여 충북 청원 육우 농가에서 18 개월간 사양시험을 수행하였다.

\section{조사항목}

시험사료의 일반성분 함량은 각각의 샘플 $(2 \mathrm{~kg})$ 을 수집하여 $\mathrm{AOAC}$ [1] 방법에 준하여 분석하였다. 체중조사는 시험개시일 부터 종료 시까지 우사 내에 위치한 우형기(CAS Korea, Newton HT-501A)를 이용하여 매월 오전 사료급여 전에 수행 하였다. 증체량은 개시체중에서 매월 측정된 값의 차로 구하 였고, 각 처리별 평균값을 시험일수로 나누어 일당증체량을 구하였다. 사료섭취량은 오전 사료 급여 전 잔량을 조사한 후 전날 급여량에서 뺀 값을 섭취량으로 간주하였다. 도체조사는 사양시험이 종료된 공시축을 출하하여 도축한 후, $0^{\circ} \mathrm{C}$ 에서 18 24시간 동안 도체를 현수시킨 후 육량판정요인(도체중, 등 지방두께, 배최장근단면적)과 육질판정요인(근내지방도, 육 색, 지방색, 조직감, 성숙도)을 소도체등급 판정기준에 의거하 여 축산물 등급판정사가 평가하였다.

\section{통계처리}

본 시험에서 얻어진 성적들은 SAS(Statistical Analysis System software, 1999)를 이용하여 분산분석 및 처리구간 유 의성 $(p<0.05)$ 을 검증하였다.

\section{결과 및 고찰}

체중, 일당증체량 및 사료섭취량

홀스타인 거세우(5개월령, 평균체중 $176.6 \mathrm{~kg}$ )를 공시하여

Table 2. Fomula of concentrate used in this experiment (DM basis)

\begin{tabular}{lccc}
\hline \multirow{2}{*}{ Fomula } & \multicolumn{2}{c}{ Mixture ratio (\%) } \\
\cline { 2 - 4 } Corn & Growing & Early fattening & Late fatterning \\
Wheat & 34.12 & 25.00 & 30.00 \\
Alfalfa & 10.00 & 15.00 & 24.42 \\
Gluten & 3.00 & & 13.24 \\
Wheat bran & 20.00 & 19.21 & 4.00 \\
Tapioca & 6.00 & 3.00 & - \\
Soybean & 3.54 & 5.00 & - \\
Sesame & 3.89 & - & 3.00 \\
Rapseed & 5.00 & 5.00 & - \\
Coconut & 3.00 & 5.00 & 5.82 \\
Molasses & 3.60 & & 5.00 \\
Limestone & 5.00 & 5.00 & 0.83 \\
Miner Mixture & 1.06 & 0.76 & - \\
NaHCO3 & 0.13 & 0.10 & 0.70 \\
Vitamin Mixture & - & 0.70 & 0.03 \\
Palm kernel meal & 0.07 & 0.03 & 7.00 \\
Salt & 5.00 & 3.48 & - \\
Calcium phosphate & 0.60 & 0.60 & 0.04 \\
Corn cob & 0.11 & - & - \\
\end{tabular}


Table 3. Chemical composition of experimental diets

\begin{tabular}{|c|c|c|c|c|c|c|}
\hline \multirow{2}{*}{ Item } & \multicolumn{3}{|c|}{ Concentrate } & \multirow{2}{*}{ Rye silage } & \multirow{2}{*}{ Timothy } & \multirow{2}{*}{ Rice straw } \\
\hline & Growing & Early fattening & Late fatterning & & & \\
\hline $\mathrm{DM}^{1)}(\%)$ & 87.82 & 87.56 & 87.41 & 10.74 & 9.04 & 8.63 \\
\hline $\mathrm{CP}^{2)}(\%)$ & 15.00 & 13.00 & 12.00 & 12.96 & 8.15 & 3.26 \\
\hline $\mathrm{EE}^{3)}(\%)$ & 2.76 & 2.71 & 2.89 & 3.15 & 2.00 & 1.85 \\
\hline $\mathrm{CA}^{4)}(\%)$ & 6.45 & 5.81 & 5.17 & 7.31 & 6.63 & 9.79 \\
\hline $\mathrm{CF}^{5)}(\%)$ & 8.66 & 6.08 & 4.86 & 27.36 & 28.78 & 27.79 \\
\hline $\mathrm{NDF}^{6)}(\%)$ & 23.94 & 18.81 & 18.62 & 56.55 & 64.60 & 66.15 \\
\hline $\operatorname{ADF}^{7)}(\%)$ & 12.19 & 8.88 & 8.55 & 31.40 & 34.72 & 36.42 \\
\hline
\end{tabular}

${ }^{1)} \mathrm{DM}$ : Dry matter.

${ }^{2)} \mathrm{CP}$ : Crude protein.

${ }^{3)} \mathrm{EE}$ : Ether extract.

${ }^{4)} \mathrm{CF}$ : Crude fiber.

${ }^{5)} \mathrm{CA}$ : Crude Ash.

${ }^{6} \mathrm{NDF}$ : Neutral detergent fiber.

${ }^{7)} \mathrm{ADF}$ : Acid detergent fiber.

Table 4. Effects of feed additives at different growth stages on growth performance and feed intake of Holstein steers

\begin{tabular}{lccc}
\hline Item & Con & T1 & T2 \\
\hline Initial BW (kg) & $175.4 \pm 7.10^{1)}$ & $179.4 \pm 5.90$ & $175.1 \pm 5.70$ \\
Final BW (kg) & $789.4 \pm 22.90$ & $808.8 \pm 14.90$ & $777.5 \pm 14.10$ \\
ADG (kg/d) & & & $1.27 \pm 0.04$ \\
Growing & $1.28 \pm 0.05$ & $1.24 \pm 0.02$ & $1.30 \pm 0.05$ \\
Early-fattening & $1.23 \pm 0.04$ & $1.30 \pm 0.04$ & $0.92 \pm 0.02^{\mathrm{b}}$ \\
Late-fattening & $1.04 \pm 0.06^{\mathrm{ab}}$ & $1.09 \pm 0.04^{\mathrm{a}}$ & \\
Feed intake (kg) & & & $5.23 \pm 0.60$ \\
Growing & & & $3.62 \pm 1.50$ \\
Concentrate & $5.25 \pm 0.55$ & $5.23 \pm 0.60$ & $7.79 \pm 1.54$ \\
Hay/Rice straw & $3.44 \pm 1.65$ & $3.63 \pm 1.54$ & $8.51 \pm 1.18$ \\
DM intake & $7.65 \pm 1.66$ & $7.79 \pm 1.58$ & $3.27 \pm 0.17$ \\
Early-fattening & & & $10.36 \pm 1.07$ \\
Concentrate & $8.51 \pm 1.18$ & $8.51 \pm 1.18$ & $11.14 \pm 0.68$ \\
Rice straw & $3.28 \pm 0.18$ & $3.27 \pm 0.16$ & $3.19 \pm 0.22$ \\
DM intake & $10.38 \pm 1.07$ & $10.37 \pm 1.07$ & $12.61 \pm 0.50$ \\
Late-fattening & & & $6.14 \pm 0.20$ \\
Concentrate & $11.19 \pm 0.70$ & $11.08 \pm 0.68$ & $8.03 \pm 0.31$ \\
Rice straw & $3.20 \pm 0.24$ & $3.20 \pm 0.23$ & $13.77 \pm 0.33^{\mathrm{a}}$ \\
DM intake & $12.66 \pm 0.48$ & $12.57 \pm 0.50$ & \\
Feed conversion ratio & & & \\
Growing & $6.00 \pm 0.22$ & $6.25 \pm 0.11$ & $8.02 \pm 0.27$ \\
Early-fattening & $8.43 \pm 0.25$ & $11.67 \pm 0.50^{\mathrm{b}}$ & \\
Late-fattening & $12.46 \pm 0.69^{\mathrm{ab}}$ & &
\end{tabular}

${ }^{1)}$ Means \pm standard error of mean.

${ }^{a, b}$ Means with different superscripts in the same row differ significantly $(p<0.05)$.

성장단계별 발육 및 사료섭취량을 조사한 결과는 다음과 같다 (Table 4). 일당증체량에 있어 육성기에서는 대조구가 가장 높 았고, 비육전기는 처리구(T1 및 T2)에서 높은 경향을 나타내었 지만, 유의적 차이는 없었다. 하지만, 비육후기에서는 $\mathrm{T} 1$ 처리 구가 $\mathrm{T} 2$ 처리구 보다 유의적으로 높게 나타났고 $(p<0.05)$, 대조
구와는 유의적 차이가 없었다. 종료체중에서 대조구, $\mathrm{T} 1$ 및 $\mathrm{T} 2$ 처리구가 각각 789.4, 808.8 및 $777.5 \mathrm{~kg}$ 으로 T1처리구의 증체량이 가장 많았지만, 유의적 차이는 없었다. 사료섭취량 은 육성기 및 비육기에서 처리구별 차이가 없었고, 건물섭취 량 또한 동일한 결과를 나타내었다. 사료요구율은 육성기에서 
Table 5. Effects of feed additives on carcass characteristics of Holstein steers

\begin{tabular}{lccc}
\hline Item & Con & T1 & T2 \\
\hline Yield traits & & & $464.4 \pm 13.1$ \\
Carcass weight (kg) & $461.9 \pm 15.2^{1)}$ & $464.6 \pm 14.4$ & $5.9 \pm 0.5$ \\
Back fat thickness (mm) & $8.7 \pm 1.0$ & $8.1 \pm 1.3$ & $73.4 \pm 4.1$ \\
Rib eye area (cm $\left.{ }^{2}\right)$ & $78.7 \pm 3.3$ & $77.5 \pm 2.3$ & $62.9 \pm 0.5$ \\
Yield index & $61.9 \pm 0.9$ & $62.0 \pm 0.8$ & $0: 87: 13$ \\
Yield grade (A:B:C, \%) & $0: 71: 29$ & $0: 50: 50$ & $2.1 \pm 0.4^{\mathrm{b}}$ \\
Quality traits & $2.4 \pm 0.5^{\mathrm{ab}}$ & $3.6 \pm 0.5^{\mathrm{a}}$ & $5.1 \pm 0.2$ \\
Marbling score (No.) & $4.9 \pm 0.3$ & $4.9 \pm 0.3$ & $3.0 \pm 0.0^{\mathrm{a}}$ \\
Meat color (No.) & $2.7 \pm 0.2^{\mathrm{ab}}$ & $2.5 \pm 0.2^{\mathrm{b}}$ & $1.8 \pm 0.2$ \\
Fat color (No.) & $2.0 \pm 0.0$ & $1.9 \pm 0.1$ & $2.1 \pm 0.1$ \\
Texture (No.) & $2.1 \pm 0.1$ & $2.1 \pm 0.1$ & $0: 0: 25: 38: 37$ \\
Maturity (No.) & $0: 0: 14: 72: 14$ & $0: 13: 37: 50: 0$ & \\
Quality grade (1 $\left.{ }^{++}: 1^{+}: 1: 2: 3, \%\right)$ & & &
\end{tabular}

${ }^{1)}$ Means \pm standard error of mean.

${ }^{a, b}$ Means with different superscripts in the same row differ significantly $(p<0.05)$.

는 대조구가 비육전기에서는 처리구가 낮은 경향을 나타내었 지만, 유의적 차이는 없었다. 비육후기에서는 $\mathrm{T} 2$ 처리구가 $\mathrm{T} 1$ 처리구에 비해 유의적으로 높았지만 $(p<0.05)$, 대조구와는 차 이가 없었다.

이전의 연구에서 거세우에 아연의 급여는 육성기 및 비육후 기에서 일당증체량을 향상시킨다고 보고하였고[15,17], 다른 연구에서도 육성기 암소의 일당증체량 및 사료요구율에 있어 향상된 결과를 나타내었다[18]. 그러나, Nunnery [13]은 증체 및 사료요구율에 있어 영향을 주지 않는다고 하였다[7,12]. 유 황의 급여는 거세우의 사료요구율은 향상되지만 일당증체에 는 영향을 주지 않는 것으로 보고되었고[20], 콜린과 라이신은 발육 및 사료요구율을 향상시키지만 고농도의 콜린의 급여는 증체에 향상된 결과를 나타내지 않았다고 하였는데[3,5,21]. 현 재의 연구에서도 콜린의 양이 $32 \mathrm{~g} / \mathrm{d}$ 의 높은 농도로 인해 증 체 및 사료요구율 향상에 영향을 준 것으로 판단된다.

따라서, 홀스타인 거세우의 발육 향상을 위해 급여한 첨가 제 중 $\mathrm{T} 1$ (아연, 유황, 비타민C) 급여구가 T2 (콜린, 라이신) 급여구 보다 발육에 있어 향상된 결과를 나타내었지만, 대조 구에 비해 유의적 차이를 나타내지 못하였기 때문에 발육 향 상에 영향을 주지 못한 것으로 판단된다.

\section{도체특성}

홀스타인 거세우 24 두를 공시하여 육질개선을 위한 첨가제 를 급여한 후 도체특성을 조사한 결과는 Table 5와 같다. 처리 구별 육량특성에 있어 도체중은 유의적 차이는 없었고, 대조 구에 비해 처리구에서 조금 높았다. 등지방두께 및 등심단면 적에서 대조구가 각각 $8.7 \mathrm{~mm}$ 및 $78.7 \mathrm{~cm}^{2}$ 로 $\mathrm{T} 1$ 과 $\mathrm{T} 2$ 처리구 의 각각 $8.1 \mathrm{~mm}, 77.5 \mathrm{~cm}^{2}$ 와 $5.9 \mathrm{~mm}, 73.4 \mathrm{~cm}^{2}$ 보다 높은 경향 을 나타내었지만 처리구간 유의적 차이는 없었다. 특히 $\mathrm{T} 2$ 처 리구가 대조구에 비해 등지방 두께가 얇고 등심단면적이 작았
다. 육량지수 및 육량등급에 있어서도 처리구간 유의적 차이 는 없었지만, 처리구간 육량지수에 있어 비슷한 경향을 나타 내었다. T2 처리구에서 육량등급 출현율(B등급 이상 $87 \%$ )도 좋았다. 육질특성에 있어서는 육색, 조직감 및 성숙도에 있어 서 처리구간 차이는 없었다. 하지만, 지방색에서는 $\mathrm{T} 2$ 처리구 가 $\mathrm{T} 1$ 보다 유의적으로 높게 나타났고 $(p<0.05)$, 대조구 보다 높 은 경향을 나타내었지만 유의적 차이는 없었다. 하지만, 근내 지방도을 제외한 육질등급 판정요인(육색, 지방색, 성숙도 및 조직감)은 처리구간 모두 등급하락 요인이 아닌 정상범위로 나타났다. 근내지방도는 대조구, $\mathrm{T} 1$ 및 $\mathrm{T} 2$ 처리구가 각각 2.4, 3.6 및 2.1로 $\mathrm{T} 1$ 처리구가 가장 높게 나타났고, 대조구와는 유의 적 차이가 없었지만, $\mathrm{T} 2$ 보다 유의적으로 높게 나타났다 ( $p<0.05)$. 또한 육질등급 출현율에 있어서도 $\mathrm{T} 1$ 처리구가 1 등급 이상 출현율이 $50 \%$ 로 대조구 $(14 \%)$ 및 $\mathrm{T} 2(25 \%)$ 처리에 보다 높았다. 이전의 연구에서는 아연과 메치오닌을 거세우에 혼합 급여하였을 때 근내지방에 영향을 주지 않는다고 하였고[11], 콜린의 급여량이 $20 \mathrm{~g} / \mathrm{d}$ 이상에서 도체특성에 긍정적인 결과 를 나타내지 않는다고 하였다[3,5,21]. 하지만, Greene 등[7]은 거세우에 아연과 메치오닌의 혼합급여는 근내지방 및 육량지 수를 향상시킨다고 하였고, 수소에 아연의 급여는 대조구에 비해 근내지방이 높은 경향을 나타내었다고 하였다[11].

본 연구에서도 라이신과 콜린의 급여구는 대조구에 비해 육질특성에 있어 영향을 주지 못한 반면, 아연, 비타민 C 및 유황 급여구는 근내지방에 있어 개선된 경향을 나타내었다.

\section{감사의 글}

본 연구는 육우산업 발전을 위하여 삼양사(주)의 일부 연 구비 지원에 의해 이루어진 연구수행 결과로 이에 감사 드 립니다. 


\section{References}

1. A.O.A.C. 1995. Official method of analysis. 16th eds. Association of Official Analytical Chemists. Washington, DC. USA.

2. Barton, J. S., L. S. Bull, and R. W. Hemken. 1971. Effect of various levels of sulfur upon cellulose digestion in purified diets and lignocellulose digestion in corn fodder pellets in vitro. J. Anim Sci. 33, 682-685.

3. Bindel, D. J., J. S. Drouillard, E. C. Titgemeyer, R. H. Wessels, and C. A. Loest. 2000. Effects of ruminally protected choline and dietary fat on performance and blood metabolites of finishing heifers. J. Anim Sci. 78, 2497-2503.

4. Chesters, J. K. 1997. Zinc. In O'Dell, B. S. and R. A. Sunde (eds.), pp. 185, Handbook of Nutritionally Essential Mineral Elements. Marcel Dekker, New York.

5. Drouillard, J. S., A. S. Flake, and G. L. Kuhl. 1998. Effects of added fat, degradable intake protein, and ruminally protected choline in diets of finishing steers. pp. 71-75, Cattlemen's Day Rep. Prog. 804. Kansas Agric. Exp. Sta., Manhattan.

6. Evans, J. L. and G. K. Davis. 1966. Influence of sulfur, molybdenum, phosphorus and copper interrelationships in cattle upon cellulose digestion in vivo and in vitro. J. Anim Sci. 25, 1014-1018.

7. Greene, L. W., D. K. Lunt, F. M. Byers, N. K. Chirase, C. E. Richmond, R. E. Knutson, and G. T. Schelling. 1988. Performance and carcass quality of steers supplemented with zinc oxide or zinc methionine. J. Anim Sci. 66, 1818-1823.

8. Harbers, C. A. Z., D. L. Harrison, and D. H. Kropf. 1981. Ascorbic acid effects on bovine muscle pigments in the presence of radiant energy. J. Food Sci. 46, 7-12.

9. Hussein, H. S. and L. L. Berger. 1995. Feedlot performance and carcass characteristics of holstein steers as affected by source of dietary protein and level of ruminally protected lysine and methionine. J. Anim Sci. 73, 3503-3509.

10. Kennedy, L. G., G. E. Mitchell, Jr. and C. O. Little. 1971. Influence of sulfur on in vitro starch digestion by rumen microorganisms. J. Anim Sci. 32, 359-363.

11. Kesslera, J., I. Morel, P.-A. Dufey, A. Gutzwiller, A. Stern, and H. Geyer. 2003. Effect of organic zinc sources on per- formance, zinc status and carcass, meat and claw quality in fattening bulls. Livestock Production Sci. 81, 161-171.

12. Malcolm-Callis, K. J., G. C. Duff, S. A. Gunter, E. B. Kegley, and D. A. Vermeire. 2000. Effects of supplemental zinc concentration and source on performance, carcass characteristics, and serum values in finishing beef steers. J. Anim Sci. 78, 2801-2808.

13. Nunnery, G. A., J. T. Vasconcelos, C. H. Parsons, G. B. Salyer, P. J. Defoor, F. R. Valdez, and M. L. Galyean. 2007. Effects of source of supplemental zinc on performance and humoral immunity in beef heifers. J. Anim Sci. 85, 2304-2313.

14. Park, B. K., S. M. Lee, H. C. Kim, S. S. Chang, T. I. Kim, Y. M. Cho, C. W. Choi, S. K. Hong, and E. G. Kwon. 2010. Effects of ruminally protected amino acid-enriched fatty acids on growth performance and carcass characteristics of fattening Hanwoo cows. J. Anim Sci. Tech 52, 499-504.

15. Perry, T. W., W. M. Beeson, W. H. Smith, and M. T. Mohler. 1968. Value of zinc supplementation of natural rations for fattening beef cattle. J. Anim Sci. 27, 1674-1677.

16. Sanders, S. k., J. B. Morgan, D. M. Wulf, J. D. Tatum, S. N. Williams, and G. C. Smith. 1997. Vitamin E supplementation of cattle and shelf-life of beef for the Japanese market. J. Anim Sci. 75, 2634-2640.

17. Spears, J. W. and E. B. Kegley. 2002. Effect of zinc source (zinc oxide vs zinc proteinate) and level on performance, carcass characteristics, and immune response of growing and finishing steers. J. Anim Sci. 80, 2747-2752.

18. Spears, J. W. 1989. Zinc methionine for ruminants: relative bioavaiability of zinc in lambs and effects of growth and performance of growing heifers. J. Anim Sci. 67, 835-843.

19. Stake, P. E., W. J. Miller, and R. P. Gentry. 1973. Zinc metabolism and homeostasis in ruminants as affected by dietary energy intake and growth rate. Proc. Soc. Exp. Biol. Med 142, 494-496.

20. Thompson, L. H., M. B. Wise, R. W. Harvey, and E. R. Barrick. 1972. Starea, urea and sulfur in beef cattle rations. J. Anim Sci. 35, 474-480.

21. Wright, M. D. and S. C. Loerch. 1988. Effects of rumen-protected amino acids on ruminant nitrogen balance, plasma amino acid concentrations and performance. J. Anim Sci. 66, 2014-2027. 


\section{초록 : 첨가물질의 급여가 홀스타인 거세우의 발육, 도체특성에 미치는 영향}

조원모 ${ }^{1} \cdot$ 양승학 ${ }^{1} \cdot$ 이상민 ${ }^{1} \cdot$ 장선식 ${ }^{1} \cdot$ 김형철 $^{1} \cdot$ 홍성구 $^{1} \cdot$ 박웅렬 $^{2} \cdot$ 김현수 $^{3}$

(농촌진흥청 국립축산과학원, ${ }^{2}$ 삼양사, ${ }^{3}$ 시네바이오)

본 연구는 육질향상을 위한 여러가지 첨가물질을 홀스타인 거세우의 성장과 도체특성에 미치는 급여효과를 구명하기 위해 수행하였다. 생후 5개월령 평균체중 $176.6 \mathrm{~kg}$, 홀스타인 거세우 24 두를 3 처리 8 반복으로 완전 임의 배치하여 사양시험을 수행하였다. 처리구는 대조구(무첨가구), T1 (Vitamin C, 아연 및 유황 급여구) 및 T2 (콜린 및 라이신 급여구)로 배치하였다. 일당증체량은 육성기와 비육전기에서는 처리구별 차이가 없었지만, 비육후기에 서는 T1처리구가 T2 처리구보다 유의적으로 높았다( $p<0.05)$. T1 처리구의 출하체중은 다른 처리구 보다 비교적 높았지만 유의적 차이는 없었다. 첨가제는 시험기간 동안 섭취량에 있어 영향을 주지는 않았지만, 비육후기 T1 처리구의 사료요구율이 $\mathrm{T} 2$ 처리구 보다 유의적으로 낮았다. 육량특성에 있어 도체중 및 육량지수는 그륩간 비슷 한 결과를 나타내었지만, 등지방 두께 및 등심단면적은 다른 처리구에 비해 T2 처리구가 비교적 낮았다. 육질특 성에서는 육색, 조직감 및 성숙도는 세 처리구에서 유의적 차이를 나타내지 않았지만, 근내지방도 및 육질1등급 이상 출현율에 있어서 $\mathrm{T} 2$ 처리구와 비교하여 $\mathrm{T} 1$ 처리구가 높았다. 따라서, 본 연구의 결과 비타민 $\mathrm{C}$, 아연, 유황 첨가는 홀스타인 거세우의 성장 및 도체특성을 향상시키는 것으로 생각된다. 